\title{
ACCENTUATION OF PERSONALITY TRAITS OF TEENAGERS: GENDER AND AGE- RELATED FEATURES
}

\section{Щудро С. А. Акцентуації характеру підлітків: гендерні й вікові особливості}

Аналіз проблеми специфічних преморбідних психологічних особливостей у підлітків 15 - 17 років визначає декілька напрямків: темпераменту, характеру, особистості, а також окремих психічних функцій.

Мета роботи - виявити вікові та гендерні особливості акцентуацій характеру підлітків 15-17 років.

Під час досліджень, які проводились у загальноосвітніх школах м. Дніпро, було обстежено 2406 підлітків, серед них: 1179 юнаків і 1227 дівчат, а саме у віці 15 років - 384 і 402, у віці 16 років - 393 та 411, у віці 17 років - 402 і 414 осіб відповідно. Серед обстежених підлітків виокремлено 120 юнаків і дівчат, у яких проводилося повне клінічне, функціональне, психологічне та соціологічне обстеження. Для визначення акцентуацій характеру використовували “Опитувальник Шмішека".

У роботі показано, що юнаки 15 - 17 років відмічались загостренням і поширеністю збудливої, гіпертимної та екзальтованої акцентуаціями; із частими комбінаціями педантичної, гіпертимної та циклотимічної. Дівчата цього віку характеризувалися більшою виразністю тривожної, емотивної та циклотимічної акцентуацій; поширеністю екзальтованої, гіпертимної та емотивної; із частими комбінаціями гіпертимної, емотивної, циклотимічної та екзальтованої.

До особливостей акцентуацій характеру в підлітків зараховувалося те, що в $15-$ річному віці юнакам і дівчатам були притаманні загострення й поширеність збудливої, гіпертимної та екзальтованої акцентуацій; із частими комбінаціями в юнаків дистимічної, тривожної та емотивної, у дівчат - збудливої, тривожної та циклотимічної.

Юнаки 16 років визокремлювалися виразністю гіпертимної акцентуації; поширеністю гіпертимної, емотивної, циклотимічної та екзальтованої; із частими комбінаціями педантичної, збудливої та гіпертимної. Дівчата цього віку характеризувалися виразністю дистимічної й циклотимічної акцентуацій; поширеністю - екзальтованої, гіпертимної та емотивної; із частими комбінаціями гіпертимної, дистимічної та екзальтованої.

Юнакам 17 років притаманним було загострення гіпертимної, емотивної та екзальтованої акцентуацій; поширеність - збудливої, гіпертимної та екзальтованої; із частими комбінаціями - застрягаючої, гіпертимної, тривожної та екзальтованої. Дівчата цього віку визначалися виразністю дистимічної акцентуації; поширеністю - екзальтованої, гіпертимної та циклотимічної; із частими комбінаціями гіпертимної, дистимічної й тривожної.

Ключові слова: підлітки, характер, акцентуації, гендерні та вікові особливості \section{особенности \\ Щудро С. А. Акцентуации характера подростков: гендерные и возрастные}

Анализ проблемы специфических преморбидных психологических особенностей у подростков 15 - 17 лет определяет несколько направлений: темперамента, характера, личности, а также отдельных психических функцій.

Цель работы - определить возрастные и гендерные особенности акцентуаций характера подростков 15 - 17 лет. Во время исследований, которые проводились в общеобразовательных школах г. Днипро, было обследовано 2406 подростков. Среди них было 1179 юношей и 1227 девушек, из них: в возрасте 15 лет - 384 и 402, в возрасте 16 лет 393 и 411, в возрасте 17 лет - 402 и 414 человек. Среди обследованных подростков было выделено 120 юношей и девушек, у которых проводилось полное клиническое, 
функциональное, психологическое и социологическое исследование. Для определения акцентуаций характера использовали «Опросник Шмишека».

В работе показано, что юноши 15 - 17 лет отличались распространенностью возбудимой, гипекртимной и экзальтированной акцентуациями; с частими комбинациями педантичной, гипертимной и циклотимической. В этом возрасте девушки характризовались большей выраженностью тревожной, эмотивной, циклотимической акцентуациями; распространенностью экзальтированной, гипертимной, эмотивной; с частыми комбинациями гипертимной, эмотивной, циклотимической и экзальтированной.

К особенностям акцентуаций характера подростков относилось наличие у юношей и девушек 15 - летнего возраста заострение и распространенность возбудимой, гипертимной, экзальтированной акцентуаций; с частыми комбинациями у юношей дистимической, тревожной и эмотивной, а у девушек - возбудимой, тревожной и циклотимической.

Юноши 16 лет отличались выразительностью гипертимной акцентуации; распространенностью - гипертимной, эмотивной, циклотимической и экзальтированной; с частыми комбинациями педантической, возбудимой и гипертимной. Девушки этого возраста характеризовались выразительностью дистимической и циклотимической акцентуаций; распространенностью - экзальтированной, гипертимной и эмотивной; с частыми комбинациями гипертимной, дистимической и экзальтированной.

Юношам 17 лет присущи заострение гипертимной, эмотивной и экзальтированной акцентуаций; распространенность - возбудимой, гипертимной и экзальтированной; с частыми комбинации - застревающей, гипертимной, тревожной и экзальтированной. Девушки этого возраста отличались выразительностью дистимической акцентуации; распространенностью - экзальтированной, гипертимной и циклотимической; с частыми комбинациями гипертимной, дистимической и тревожной.

Ключевые слов: подростки, характер, акцентуации, гендерные, возрастные особенности

\section{Shchudro S. A. Accentuation of personality traits of teenagers: gender and age-related features.}

Analysis of the problem of specific premorbid psychological features in 15-17 year-old teenagers identifies several areas: temperament, character, personality, as well as individual mental functions.

The purpose of the work is to identify age-related and gender peculiarities of accentuation of 15-17 year-old teenagers' traits. 2,406 adolescents were examined during investigation in Dnipro secondary schools. There were 1179 boys and 1227 girls; 384 and 402 15-year-old teenagers, 393 and 411 16-year-old teenagers, 402 and 414 17-year-old teenagers, respectively. 120 boys and girls were singled out, who underwent a complete clinical, functional, psychological and sociological examination. The Smyshek Questionnaire was used to determine accentuations of personality traits.

It is shown that 15-17 year-old boys were marked by exacerbation and prevalence of excitatory, hypertensive and exalted accentuations; with frequent combinations of pedantic, hypertensive and cyclothymic ones. Girls of this age were more expressive, anxious, emotional and cyclothymic; dominant accentuations were exalted, hypertensive and emotional; with frequent combinations of hypertensive, emotional, cyclothymic and exalted.

The peculiarities of 15 year-old teenagers' accentuations were that boys and girls were characterized by exacerbation and prevalence of stimulating, hypertensive and exalted accentuations; with frequent combinations of dysthymic, anxious and emotional in boys; exciting, anxious and cyclothymic in girls.

The 16 year-old boys were characterized by the severity of hypertensive accentuation; with prevalence in hypertensive, emotional, cyclothymic and exalted ones frequently combined with meticulous, stimulating and hypertensive accentuations. 16 year-old girls were characterized by expressiveness of dysthymic and cyclothymic accentuations; with prevalence in exalted, hypertensive and emotional accentuation frequently combined with hypertensive, dysthymic and exalted ones. 
The 17 year-old boys had an exacerbation of hypertensive, emotional and exalted accentuations; with prevalence in excitable, hypertensive and exalted accentuations frequently combined with stuck, hypertensive, anxious and exalted ones. The 17 year-old girls were characterized by the expressiveness of dysthymic accentuation; with prevalence in exalted, hypertensive and cyclothymic accentuations frequently combined with hypertensive, dysthymic and anxiety ones.

Key words: teenagers, personality traits, accentuation, gender, age-related peculiarities

Formulation of the problem. The analysis of the problem of specific premorbid psychological characteristics in 15-17 year-old teenagers determines several directions: temperament, character, personality, as well as individual mental functions $[3 ; 8 ; 13 ; 20]$. Pathogenic significance of higher nervous activity features was noted by I. P. Pavlov [cit. for 13]. The leading providers of neurotic and psychiatric disorders are borderline variants of the norm, first of all, the "weak type". However, the possibility of their occurrence in "strong type" persons under conditions of considerable psychotraumatic influence is not excluded. Neurasthenia occurs in persons with weak or strong (unbalanced) and increased-inhibitory type; hysteria occurs in representatives of the weak artistic type with predominance of subcortical activity over cortical; psychasthenia occurs in persons of mental (meditative) type with painful predominance of cortical activity over subcortical $[6 ; 9 ; 13 ; 20]$.

V. Magnan's doctrine of the inverse proportion between the vulnerability of the nervous system and the severity of mental trauma has gained considerable popularity in contemporary literature: the more vulnerable and "neuroticized or psychopathic" the nervous system is, the less intense is the mental trauma [13].

B.D. Karvasarskybelieved that a fairly common view was the view that the "suppliers" of neuroses in the past. As a rule, there are psychopaths, and the leading forms of neuroses are decompensation of the corresponding types of psychopathies (hysteria is hysteroid psychopathy, neurosis of obsessive conditions is psychopathy of the psychostenic circle), comparing the correlation between traits (normal and pathological) and neuroses. There is a commonly held statement in present-day psychiatry that neuroses can occur in individuals who are lack of psychopathy, as well as without any distinct psychopathic traits [6].

Yu.O. Alexandrovsky believes that the current distinction between neuroses and psychopathies, on the basis of neurosis" "psychogenic" and "functional" features, and psychopathies" "biological" and "organic" features, is rather relative. Such a distinction is relevant only for the presentation of clinical forms and variants of borderline conditions, determination of the prognosis of their course, and at the same time it is not fundamental for understanding their pathophysiological mechanisms $[1 ; 12 ; 13 ; 20]$.

If there are different views on the importance of pathologically characteristic "basis" on neurogenesis, the role of accentuation of personality traits is determined by all scientists. The theoretical background of the diagnostic type of personality accentuation is $\mathrm{K}$. Leonhard's "accentuated personalities" concept according to which personality traits can be divided into leading and additional [8; 22]. Leading traits make up the "core" of the individual. In the case of bright expressiveness, the leading traits become accentuation of personality traits. The personalities with the clearly identified leading traits are called "accentuated" by K. Leonhard. Accentuated individuals may be considered pathological, but in the case of adverse factors, accentuation can destroy the structure of the personality and become pathological [8;22].

Ten types of accentuated persons, which were defined by K. Leonhard, are sometimes can be divided into 2 groups of accentuation of personality traits (demonstrative, pedantic, apprehensive, excitable) and accentuation of temperament (hyperthymic, dysthymic, anxious-timid, cyclothymic, affective, emotive) $[8 ; 22]$.

A specific type of accentuation of personality traits is inherent in certain forms of neurotic disorders. Astheno-neurotic and labile types of accentuation are factors that contribute to the emergence of certain neurasthenia conditions; sensitive, psychasthenic and asthenic-neurotic types are favourable grounds for the development of obsessive-phobic neurosis $[13 ; 20]$. 
Hysterical neurosis occurs on the background of the hysteroid or some mixed one with the hysteroid types such as labile-hysteroid, hysteroid-epileptoid, schizoid-hysteroid. A.E. Lichko notes that the type of accentuation depends not only on the peculiarities of the clinical picture of neurosis, but also on the selective sensitivity to certain psychogenic factors, assessing the importance of highlighting the concept of "accentuation of personality traits". It happens since neurotic decompensation can be caused by psychotraumatization, which requires extravagance to "spheres of least resistance" of this type of accentuation [9; 12].

Analysis of scientific research. The risk factors for mental health disorders are investigated with the analysis of the characteristics of teenagers' temperament and nature in psychological and sociological studies $[5 ; 14 ; 17]$.

Destabilization processes in society, psycho-emotional abuse in families and educational institutions are reflected in the mental development of children and teenagers. The system of training and professional development of medical and pedagogical workers is being improved; new methods and approaches aimed at preventing and recognizing pathology and timely treatment are being introduced in order to reduce their incidence of mental and behavioral disorders in Ukraine [17].

A number of studies have identified the factors that determine the formation of teenagers' deviant behavior: education in hypo-surveillance, single parent, low level of material support, conflict in families, high proportion of cerebral-organic factors, and neuropathy in early childhood, the presence of neurosis, difficulties in school adaptation, communicative deviance, and school curriculum overload.

The greatest share among school-aged teenagers had: aggression (69.4\%), character reaction in the form of protest $(34.5 \%)$, negativism (34.5\%), opposition $(30.0 \%)$, queerliness $(24.4 \%)$, the grouping reaction $(24.4 \%)$. The second place is shared by behavior deviations $(20.8 \%)$, substance abuse and smoking $(18.7 \%)$, drinking alcohol $(18.1 \%)$, immoral behavior $(12.6 \%)$, overvalued psychological hobbies $(12.2 \%)$, communicative deviations $(10.3 \%)$. Third place is shared by computer addiction (5.6\%), autism (5.4\%), gambling (5.4\%), autoarchy (3.2\%), eating disorders in the form of overeating $(2.4 \%)$, starvation $(1.5 \%)$, kleptomania $(1.1 \%)$, religious fanaticism $(0.9$ $\%$ ), anesthesia ( $0.9 \%$ ). There are $43.5 \%$ of students who have low control of aggression, $31.8 \%$ of students who show aggression as a trait, and $14.8 \%$ of students who shows aggression as a condition [19].

A number of researchers have identified a likely higher number of individuals with low collective, high self-efficacy, self-confidence, oriented towards the acquisition of their own life experience dependence (factor Q2) in 15-17 year-old teenagers [14; 16]. Teenagers with depressive neurotic disorders have a high proportion of the level of neuroticism on the scale of neurotic depression $(92.5 \%)$, anxiety (30.0\%), obsessive-phobic disorders $(36.3 \%)$, autonomic disorders $(36.3 \%)$. The maximum level on the asthenia scale is defined; while the level on the hysterical response scale is reduced in almost all teenagers with depressive neurotic disorders. A certain constellation of the rises in the severity of the neurotic component is determined as neurotic depression (-34.5 points), anxiety (-22.7 points) in teenagers with depressive neurotic disorders [7].

Significant differences between the factors C, D, G, L were found among the factors characterizing the emotional-volitional features. A considerable number of students had a greater level of emotional instability, low tolerance for frustration, high sensitivity, tendency to change mood, irritability, increased fatigue, tendency to neurotic syndromes, hypochondria (factor -C). They were characterized by a lower degree of excitability, impulsiveness, characterized by prudence, silence, care and prudence. The tendency for complications and pessimistic perception of reality (factor -D) was also characteristic of students. The teenagers were characterized by a higher degree of perception of social norms, conscious compliance with the rules of conduct, purposefulness in achieving the goal, accuracy, responsibility, business orientation (factor -G). Their traits were a high level of firmness, courage, self-confidence, prudence, realistic judgment, practicality, insensitivity to others (factor -L) [5; 14].

Factors A, E, H, J, which characterize the communicative properties and features of interpersonal relationships, have significant differences in teenagers. Most students had a clear cyclothymia, individuals with a preference for these features are more open and kind, they are 
inherent in naturalness and immediacy. However, this factor may indicate the inconsistency and tendency to affectitis of the person (factor + A). They have a high level of obedience; people with a preference for this trait are more timid, inclined to pave the way for another. They tend to be respectful, but their submissiveness can be completely passive (factor -E). There is a high level of social courage, activity, readiness to deal with unfamiliar circumstances and people. They are more risk-averse, significantly loose and unbuttoned $(+\mathrm{H}$ factor). They are characterized by a high level of conformism, collectivism, while the individual is more dependent on the group, social thought, he / she prefers collective types of work and decision-making, focuses on social approval, such individuals often lack initiative in decision-making (factor-J) $[5 ; 14]$.

The use of statistical methods for the study of psychological characteristics of the 14-16 yearold boys and girls showed that such clusters as character (the leading indicators of traits), anxious (indicators of situational anxiety and characteristics of neuro-psychological tension), accentuatedtemperamental-logical (degree of extraversion of personality and accentuation of personal traits), neurotic (indicators of neuroticism of personality), neuro-psychic and (indicators of neuro-mental state), coordination (coordination of the organism abilities), educational-significant (influence of educational activity on the functional state of teenagers), cognitive-significant (influence of cognitive activity on the functional state of teenagers), visual-motor (characteristics of visual-motor reaction), visual-sensory (characteristics of visual-sensory reaction) were identified in students who studied in innovative institutions [10].

Assessment of students' psycho-hygienic indicators shows that there is a significant percentage of high indicators of neuroticism, situational and personality anxiety, as well as types of personality accentuation such as hypertensive, exalted, cyclothymic in the teenagers. The level of neuroticism ranges from $13.68 \pm 0.92$ to $15.88 \pm 0.77$ points for girls, and from $11.25 \pm 0.81$ to $13.20 \pm 0.93$ points for boys. However, $50.0 \%$ of 12 -year-old adolescents have an increased level of neuroticism in the distribution structure, and half of these individuals have very high indicators; the 13-14 year-old individuals have the increased level, which is $40.0 \%$, and the 15 year-old individuals have only $25 \%$. Thus, there is a tendency to decrease with age. An increased level of neuroticism is found only in $30.0 \%$ of 12 year-old girls, that is gradually increasing; and it is already detected in $53.0 \%$ of the examined 15 year-old girls.

The strongest correlation was found between indicators of neuroticism and personal anxiety, a clear correlation was found between high values for screening cardiac, pulmonological, endocrine, and psychological disorders in students' health and accentuation of excitatory, dysthymic and exalted types. High rates of neuroticism and personal anxiety correlated with signs of pathology of the urogenital, cardiovascular, endocrine, respiratory systems and with indicators of psychological disorders $[4 ; 15]$. Therefore, the study of accentuation of the personal traits of 15-17 year-old students is essential for understanding the causes of mental disorders in the current conditions of adjustment of secondary education.

The purpose of the work is to identify age-related and gender peculiarities of accentuation of 15-17 year-old teenagers' traits.

Presentation of basic material and research results. There were 2,406 teenagers examined during surveys conducted in Dnipro secondary schools. There were 1179 boys and 1227 girls; 15 year-old individuals - 384 and 402; 16 year-old individuals - 393 and 411; 17 year-old individuals -402 and 414 respectively.

Examined 120 boys and girls were singled out who underwent a complete clinical, functional, psychological and sociological examination and treatment-and-prophylactic measures.

The criterion for inclusion in the study was 15-17 year-old boys and girls, who studied in the 9-11th forms of secondary schools. Exclusion criteria were young children; students of colleges, lyceums and boarding schools; the presence of endogenous mental disorders and comorbidities in exacerbated stages in boys and girls that affect their quality of life; refusal of examination and treatment. Parents of all teenagers as well as boys and girls agreed to participate in the study.

The Smyshek Questionnaire was used to determine accentuation of personal traits. The test consists of 10 scales and 88 questions according to the 10 types of accentuations by K. Leonhard. Using certain keys makes it possible to find the sum of "raw points" on each scale. The product of the raw score and the coefficient gives an indicator of the type of accentuation. An indicator can be 
considered as expressive and accentuated features are likely if it is $>19$ points, although it is $>12$ points by some authors. The maximum sum of points after multiplication is 24 . The sum of points from 14 to 19 indicates only the tendency to one or another type of accentuation, and it is possible to state certain probability about accentuation of a person of a certain type only with the sum of points $>19[8 ; 21 ; 22]$.

Methods of mathematical statistics were used to process the study results. A comparison was made between the data obtained from boys and girls and between the results of a survey of the 15, 16, 17 year-old teenagers. Statistical evaluation of the sample included primary statistical analysis: estimation of arithmetic mean (M), root mean square deviation (S), error of arithmetic mean (m). Homogeneity criteria were used to estimate differences between the samples. The confidence level (p) was considered to be $>0.95[18]$.

Correlation analysis was used to examine the correlation between two or more variables; correlation made it possible to make statistical conclusions about the dependency between the variables [2].

Statistical processing of the study results was performed using VerMed software [11].

The data we received indicate that mixed accentuations were found in $93.8 \%$, and unmixed accentuations were found in $6.2 \%$ of the surveyed tenagers. There were identified ten types of teenagers' accentuation: demonstrative, apprehensive, pedantic, excitable, hypertensive, dysthymic, anxious, emotional, cyclothymic and exalted.

Boys of 15-17 years were marked by exacerbation of anxious, emotional and cyclothymic accentuation of personality traits. Among all the accentuations, the hypertensive one was observed in $76.5 \%$, the exalted one was observed in $64.7 \%$, the excitatory one - in $52.3 \%$, emotional - in $41.2 \%$, cyclothymic - in $29.4 \%$, demonstrative - in $23.5 \%$ of the examined teen-boys. Anxious and emotional accentuation correlated with the pedantic one, while cyclothymic accentuation correlated with the demonstrative one. Girls of 15-17 years were characterized by authentic expressiveness of anxious, emotional and cyclothymic accentuations. Exalted accentuation was found in $90.3 \%$, hypertensive - in $83.9 \%$.

There are age-related and gender differences in the types of tennagers' accentuation.

Exacerbated, hypertensive and exalted accentuation were aggravated in 15 year-old boys and girls. Teen-boys had excitatory accentuation in $83.3 \%$, exalted in $83.3 \%$, hypertensive in $66.7 \%$, emotional in $50.0 \%$, cyclothymic in $33.3 \%$, demonstrative in $16.7 \%$ of examined cases. Their exciting accentuation correlated with dysthymic, anxious and exalted ones; hypertensive accentuation correlated with demonstrative, dysthymic, emotional and cyclothymic ones; exalted accentuation correlated with excitement and anxiety ones.

Exclusive accentuation was identified in $88.8 \%$ of 15 year-old girls' cases, cyclothymic - in $88.8 \%$, emotional - in $77.7 \%$, hypertensive - in $77.7 \%$, demonstrative - in $44.4 \%$, excitable - in $44.4 \%$, pedantic - in $22.2 \%$, stuck - in $11.1 \%$ of cases. They have exciting accentuation associated with stunting, pedantic, hypertensive and cyclothymic ones; while hypertensive accentuation was associated with excitement, anxiety and cyclothymic ones; exalted accentuation was associated with anxiety.

The 16-year-old boys are characterized by significant expressiveness of hypertensive accentuation, which was associated with delusional, pedantic, excitable, anxious and emotional accentuations. Hypertensive accentuation of personality traits appeared in $100.0 \%$, emotional $50.0 \%$, cyclothymic $-50.0 \%$, exalted $-50.0 \%$, demonstrative $-33.3 \%$, excitatory $-16.7 \%$ of examined case of 16 year-aged individuals.

16 year-old girls were identified by expressiveness of dysthymic and cyclothymic accentuations. Exalted accentuation was observed in $92.3 \%$, hypertensive - in $4.6 \%$, emotional in $76.9 \%$, excitatory - in $69.2 \%$, demonstrative - in $61.5 \%$, cyclothymic - in $38.5 \%$, anxious in $23.1 \%$, pedantic - in $15.4 \%$, stuck - in $7.7 \%$ of the examined cases. Dystymic accentuation correlated with demonstrative, stimulating, hypertensive and cyclothymic ones; while cyclothymic accentuation correlated with excitement, dysthymic and exalted accentuations.

17 year-old boys had aggravated hypertensive, emotional and exalted accentuation. Excitable accentuation was identified in $60.0 \%$, hypertensive - in $60.0 \%$, exalted - in $60.0 \%$, demonstrative - in $20.0 \%$, emotional - in $20.0 \%$ of the examined cases. The hypertensive accentuation was 
associated with stunting, pedantic, dysthymic, anxious, emotional, cyclothymic and exalted ones; emotional accentuation was associated with stuck, hypertensive, exalted ones; exalted accentuation was associated with delusional, meticulous, hypertensive, anxious, emotional and cyclothymic ones.

Dysthymic accentuation which correlated with pedantic, hypertensive, anxious, cyclothymic and exalted ones was the most marked in 17 year-old girls. Exalted accentuation of personality traits was found in $88.8 \%$, hypertensive - in $88.8 \%$, cyclothymic - in $77.7 \%$, excitatory - in $66.6 \%$, emotional in $66.6 \%$, demonstrative - in $33.3 \%$, pedantic - in $22.2 \%$, stagnant - in $11.1 \%$, anxious - in $11.1 \%$ of the examined girls.

Teenagers with demonstrative accentuation of personality traits hated feeling carelessness to them, they tried to be the center of attention, wished to provoke admiration and "bowing of the head". They believed that they had artistic talent, liked to fantasize, imagined the achievement of high social status, which caused envy in others. These individuals valued only constant attention to themselves and felt that they could not find decent companions in friendship.

Boys and girls with delicate accentuation were characterized by considerable stability of affect. Affectionate personality lasts for a long time, although no new experiences support it, and even after a long period of time, the accompanying stress of emotion can easily come to life. Affect traps were most clearly manifested in cases where the interests of the accentuated individual were violated. Affect was a response to dignity, self-loathing and various forms of oppression. However, objectively negative effects could be minimized. Neglect of self-interest was never forgotten by intimidating individuals, they were vindictive.

Teenager's leading traits were extreme indecision, fear of making any decision while pedantic accentuation. Constant doubts made the work of these persons slow and unbearable. They always sought support, over-looked after their own health and the involvement of relatives; the excitement was their constant companion. They were embarrassed when they were paid attention, did not like physical activities, considered themselves as awkward and disempowered persons, and were prone to introspection and philosophy.

The students with stimulating accentuation of personality traits were incendiary, prone to unrestrained anger and fury, malicious and vulnerable, not able to pay for the insults. At the same time, they exerted excessive demands on others, were eager to give advice and did not tolerate them; sometimes such individuals had a reasonably sad mood, and they became particularly irritable.

Teenagers with hypertensive accentuation were friendly, kind, open-hearted, talkative, had many friends, were always ready to help others, but rarely kept their promises, were often optional. They did not endure the hard work that required patience and dedication. They could not often come up with original ideas. The hypertensive personalities were mocking, liked to copy people, and treated them with contempt; they did not tolerate being contradicted, they could act rudely and offensively in these cases; they disdain the hardships and the expenses.

Anxious individuals felt a sense of dread, often reaching the limit (they feared darkness, thunderstorms, predators, other children) in their childhood. These fears were counterbalanced in adolescence, but timidity with elements of obedience, humiliation, sometimes with compensation in the form of self-righteous or even impudent behavior remained. Sometimes anxious individuals felt cowardice, which was purely reflexive and it could be a manifestation of unexpected fear. Also, fear was sometimes accompanied by a somatic reaction, which intensified the fear.

Teenagers with emotional accentuation were characterized by sensuality and deep reactions in the sphere of subtle emotions, vulnerability, sensitivity and soft-heartedness. They preferred nature, admired art, easily wept for joy and sorrow; spiritual shocks have led such teenagers to deep stress, sometimes causing them to be depressed. Individuals of emotive type are unable to feel carefree joy and happiness, they take any life event much more seriously than other people.

Boys and girls with cyclothymic accentuation were characterized by changes in hyperthymic and dysthymic states, with one or the other of the two poles at the forefront, sometimes without apparent external motives, but sometimes in connection with specific events. Enjoyment made them feel not only positive emotions, but also they were accompanied by a general pattern of hypertension: a need for activity, increased talkativeness, jumps of ideas, while sad events led to depression, slowing reactions and thinking. If a fun society was going on, affective and unstable 
personalities could be in the center of attention and make everyone happy. On the contrary, they became silent and closed in a serious and restrained society.

Exalted accentuation was expressed in violent emotions on life situations, marked by the special intensity of their external manifestations. These teenagers were equally exaggerated in the ecstasy of the joyous events and in the despairing of the sad. Exaltation was motivated by subtle, altruistic motives; good will to friends and relatives, joy for their success and achievement were extremely strong. These individuals were characterized by inflammatory impulses which are not related to their own personal relationships. They were fond of music, art, nature, sports and religion. Another pole of these boys' and girls' reaction is the over-vulnerability to sad events. Pity, sympathy for unhappy people and sick animals made them feel despair. With regard to the slight failure or slight disappointment that others might have forgotten next day, the exalted persons felt deep and sincere grief; they were characterized by a sharp rise in fear, even a slight increase manifested by increased vegetative and psychic reactions.

Thus, the data obtained by us indicate that teenagers of 15-17 years were characterized by exacerbation and prevalence of excitable, hypertensive and exalted accentuations; with frequent combinations of pedantic, hypertensive and cyclothymic ones. Girls of this age were more expressive of anxious, emotional and cyclothymic accentuations; prevalence was observed in exalted, hypertensive and emotional variants with frequent combinations of hypertensive, emotional, cyclothymic and exalted accentuations. Accentuation greatly influenced the formation of traits of teenagers.

Prospects for further research. The need for continuous improvement of methods to improve health and the quality of life of young students in Ukraine requires further study of the psychological characteristics of teenagers and adolescents, their correlation with somatic and social components.

\section{Conclusions.}

1. Along with the structures and functions of the body, the structure of personality and mental functions of teenagers greatly affect their activity and participation in public life, the possibility of carrying out therapeutic and preventive measures.

2. The 15-17 year-old boys were characterized by exacerbation and prevalence of stimulating, hypertensive and exalted accentuations; with frequent combinations of pedantic, hypertensive and cyclothymic ones. Girls of this age were more expressive in anxious, emotional and cyclothymic accentuations; dominant ones were exalted, hypertensive and emotional; with frequent combinations of hypertensive, emotional, cyclothymic, and exalted accentuations.

3. Age-related and gender differences of teenagers' accentuation types were revealed. The 15 year-old boys and girls were characterized by exacerbation and prevalence of excitable, hypertensive and exalted accentuations; with frequent combinations dysthymic, anxious and emotional (for boys), and exciting, anxious and cyclothymic (for girls).

4. The 16 year-old boys were characterized by the severity of hypertensive accentuation; with prevalence in hypertensive, emotional, cyclothymic and exalted ones frequently combined with meticulous, stimulating and hypertensive accentuations. 16 year-old girls were characterized by expressiveness of dysthymic and cyclothymic accentuations; with prevalence in exalted, hypertensive and emotional accentuation frequently combined with hypertensive, dysthymic and exalted ones.

5. The 17 year-old boys had an exacerbation of hypertensive, emotional and exalted accentuations; with prevalence in excitable, hypertensive and exalted accentuations frequently combined with stuck, hypertensive, anxious and exalted ones. The 17 year-old girls were characterized by the expressiveness of dysthymic accentuation; with prevalence in exalted, hypertensive and cyclothymic accentuations frequently combined with hypertensive, dysthymic and anxiety ones.

\section{Literature}

1. Александровский Ю. А. Пограничные психические расстройства. М., 2000. 496 с.

2. Афифи А. Статистический анализ. Подход с использованием ЭВМ: [монография]. М. : Мир, 1982. 488 с. 
3. Банников Г. С. Роль личностных особенностей в формировании структуры депрессии и реакций дезадаптации. Автореф. дисс. ... к.м.н. 14.00.18. М., 1998. 22 с.

4. Безрукава Н. Ю. Використання показників психофізіологічних функцій та особливостей особистості як інтегральних критеріїв гігієнічної оцінки функціонального стану організму підлітків. Гігієна населених місць. 2007. № 50. С. 317-320.

5. Коробчанський В. О., Васильченко I. О., Витріщак С. В. Гігієнічна оцінка факторів ризику, як критеріїв якості життя підлітків різних соціальних груп/ Гігієна населених місць. 2007. № 49. С. 332-336.

6. Карвасарский Б. Д. Неврозы. М.: Медицина, 1990. 576 с.

7. Проскурина Г. Ю., Михайлова Е. А., Мителев Д.А., Матковская Т. Н. К проблеме депрессий у школьников подросткового возраста. Моніторинг здоров'я школярів: міжсекторальна взаємодія лікарів, педагогів, психологів : матеріали наук.-практ. конф. 3 міжнар. участю 21-22 жовт. 2009 р. Харків: ДУ “ІОЗДП АМНУ”, 2009. С. 91-93.

8. Леонгард К. Акцентуированная личность. Пер. с нем. В.М. Лещинской. К.: Вища школа, 1981.389 c.

9. Личко А. Е. Подростковая психиатрия. Л., 1985. 416 с.

10. Малачкова Н. В., Сергета I. В. Використання кластерного аналізу в гігієнічних дослідженнях, що спрямовані на встановлення закономірностей впливу чинників умов перебування на стан зорової сенсорної системи підлітків $14-16$ років. Гігієна населених місць. 2007. № 50. С. 314-317.

11. Мацуга О. М. Інформаційна технологія обробки неоднорідних медичних даних для підтримки прийняття рішень під час діагностики: автореф. дис. на здобуття наук. ступеня канд. техн. наук: 05.13.06 Дніпропетровськ, 2007. 18 с.

12. Менделевич В. Д., Соловьева С. М. Неврозология и психосоматическая медицина. М.: МЕДпресс-информ, 2002. 608 с.

13. Мясищев В. Н. Личность и неврозы. Л.: Изд-во Лен. ун-та, 1960. 426 с.

14. Попов О. І., Лупаренко С. С., Гончаров А. В. Орієнтація вальдорфських засобів розвитку пізнавальної активності у дітей на цілісну психічну структуру особистості як фактор зміцнення здоров’я. Гігієна населених місць. 2009. № 54. С. 335-339.

15. Сергета І. В., Безрукава Н. Ю. Інтегральний підхід до гігієнічної оцінки та моніторингу функціонального стану дітей та підлітків. Вісник морфології. 2006. № 12. С. 273-275.

16. Сергета I. В., Боровський Б. Р. Особливості розвитку психофізіологічних функцій в умовах використання програми психогігієнічної корекції функціонального стану організму, особливостей особистості і професійної придатності учнів і студентів, що здобувають спеціальності у сфері залізничного транспорту. Гігієна населених місць. 2009. № 54 . С. 290-295.

17. Сисоєнко Н. В., Сєрих Л. В., Целінко Т. В. Гігєнічна оцінка розкладів уроків в загальноосвітніх навчальних закладах 3 використанням нової рангової шкали оцінки важкості навчальних предметів. Гігієна населених місць. 2007. № 49. С. 388-392.

18. Бабак В. П., Білецький А. Я., Приставка О. П. Статистична обробка даних. К. : МІВВЦ, 2001. $388 \mathrm{c}$.

19. Михайлова Е. А., Проскуріна Т. Ю., Мітельов Д. А. Структура девіантної поведінки у підлітків та фактори, що іiі детермінують. Моніторинг здоров'я школярів: міжсекторальна взаємодія лікарів, педагогів, психологів : матеріали наук.-практ. конф. 3 міжнар. участю 2122 жовт. 2009 р. Харків: ДУ “ІОЗДП АМНУ”, 2009. С. 74-75.

20. Тополянский В. Д., Струновская М. В. Психосоматические расстройства. М.: Медицина, 1986. $384 \mathrm{c}$.

21. Шкалы, тесты и опросники в медицинской реабилитации. Под ред. А. М. Беловой, О. Н. Щепетова. М.: Антидор, 2002. 440 с.

22. Leonhard K. Akzetuieric Personlichkeiten. Berlin: Volk.u. Cresundheit, 2-e Auflage, 1976. 328 s.

\section{References}

1. Aleksandrovskiy Y. A. (2000). Pogranichniye psychycheskiye rasstroystva., 496 (rus).

2. Afifi A., Eyzen S. (1982). Statisticheskiy analiz. Podxod s ispolzovaniyem EVM., 488 (rus). 
3. Bannicov G. S. (1988). Rol lichnostnich osobennostey v formirovanii strkturi depressiyi I reactsiy desadaptacii., 22 (rus).

4. Bezrukava N. Y. (2007). Vicoristannya pokaznikiv psychofiziologichnich funktsiy ta osoblivostey osobistosti yak integralnix kriteriiv gigienichnoyi otsinki functionalnogo stanu organizmu pidlitkiv. Gigiena naselennix mistz, 50, 317-320 (ukr).

5. Korobchanskiy V. O., Vasilchenko I. O., Vitrishchak S. V. (2007). Gigienichna otshinka factoriv riziku, yak kriteriiv yakosti zhittya pidlitkiv riznix socialnix grup. Gigiena naselennich mists, 49, 332-336 (ukr).

6. Karvasarskiy B. D. (1990). Nevrozi, 576 (rus).

7. Proskurina G. Y., Michayliva E. A., Mitilev D. A., Matkovskaya T. N. (2009). K probleme depressiy u shkolnikov podrostkovogo vozrasta. Monitorong zdorovya shcolariv: materiali nauk.pract. Konf. Z mizhn. uchastyu., Harkiv, 91-93 (rus).

8. Leongard K. (1981). Aktzentuirovannay lichnost. K: Vishcha shcola, 389 (rus).

9. Lichko A. E. (1985). Podrostkovaya psichiatriya, 416 (rus).

10. Malachkova N. V., Sergeta I. V. (2007). Vikotistanya klasternogo analizy v gigienichnix doslidzhenyax, scho spramovni na vstanovlenya zakonomirnostey vplivy chinnikiv umov perebuvannya nastan sensornoyi sistemi pidlitkiv 14-16 rokiv. Gigiena naselenix mists, 50, 314317 (ukr).

11. Matsuga O. N. (2007). Informatshiyna texnologiya obrobki neodnoridnich medichnix danich dla pidtrimki priynattya rishen ped chas diagnostiki. Dnipropetrovsk, 18 (ukr).

12. Mendelevich V. D., Solovyova S. M. (2002). Nevrozologiya I psichosomaticheskaya medicina. M., MEDpress-inform, 608 (rus).

13. Myasichev V. N. (1960). Lichnost I nevrozi. L., Izd-vo Lrn. Univ-ta, 426 (rus).

14. Popov O. I., Luparenko S. E., Goncharova (2009). Orientazhiya valdorfskix zasobiv rozvitku piznavalnoyi diyalnosti u ditey na tsilisnu psichichn strkturu osobistosti yak factor zmitsnenya zdorovya. Gigiyena naselennix mistz, 54, 335-339 (ukr).

15. Sergeta I. V., Bezrukava N. Y. (2006). Integralniy pidxid do gigienichnoyi otsinki functionalnogo stanu ditey ta pidlitkiv, Vistnic morfologiyi, 12, 273-275 (ukr).

16. Sergeta I. V., Borovskiy B. P. (2009). Osoblivosti rozvitku psichofiziologichnix funktsiy v umovax vikoristannya programmi psichogigienichnoyi korrektsiyiy funktsionalnogo stan organizmu, osoblivostey osobistosti I profesiynoi pridatnosti uchniv I stdentiv, shcho zdobuvyt spetsialnosti u sferi zaliznichnogo transport, Gigiyena naselennix mistz, 54, 290-295 (ukr).

17. Sisoyenko N. V., Serix L. V., Tselienko T. V. (2007). Gigienichna otsinka rozkladiv urokiv v zagaalnoosvitnich navchalnich zakldax $\mathrm{z}$ vicoristanyam rangovoyi shkali otsinci vazhkosti navchalnix predmetiv, Gigiyena naselennix mistz, 49, 388-392 (ukr).

18. Babak V. P., Biletskiy A, Ya., Pristavka O. P. (2001). Statistichna obrobka danich, K., MIVVTs, 388 (ukr).

19. Michaylova E. A., Proskurina T. Y., Mitelev D. A. (2009). Structura deviantnoyi povedinki u pidlitkiv ta factori, shco ii determinuyut,. Monitorong zdorovya shcolariv: materiali nauk.-pract. Konf. Z mizhn. uchastyu., Harkiv, 74-75 (ukr). (rus).

20. Topolyanskiy V. D., Strnovskaya M. V. (1986). Psichosomsticheskiye rasstroystva, 384

21. Belova A. M., Shchepetova O. N. (2002). Shkali, testi I oprosniki v meditsinskoy reabilitatsii. M., Antidor, 440 (rus).

22. Leonhard K. Akzetuieric Personlichkeiten. Berlin: Volk.u. Cresundheit, 2-e Auflage, 1976. $328 \mathrm{~s}$. 